\title{
DAMPAK PEMBANGUNAN PERUMAHAN TERHADAP KONDISI LINGKUNGAN DAN AKTIVITAS MASYARAKAT DI KECAMATAN PARUNG PANJANG
}

\author{
Inggried Noveryn Pintauli ${ }^{1}$, Ratna Safitri ${ }^{2}$ \\ ${ }^{1}$ Universitas Pembangunan Jaya, email: inggriednoveryn99@gmail.com \\ ${ }^{2}$ Universitas Pembangunan Jaya, email: ratna.safitri@upj.ac.id
}

\begin{abstract}
ABSTRAK
Sudah kurang lebih selama lima tahun belakangan ini, pada Kecamatan Parung Panjang, Kabupaten Bogor, Jawa Barat terdapat adanya pembangunan perumahan dalam beberapa wilayahnya. Dari kegiatan tersebut terlihat dan terasa terjadinya perubahan kondisi lingkungan dan juga aktivitas yang dilakukan masyarakat di Kecamatan Parung Panjang secara perlahan. Penelitian ini dilakukan bertujuan untuk mengindentifikasi dampak apa saja yang terjadi bagi kondisi lingkungan, dan aktivitas masyarakat yang terjadi pada suatu wilayah desa ketika adanya pembangunan pembangunan tersebut. Penelitian ini akan dilakukan pada wilayah Kelurahan Parung Panjang terpatnya pada wilayah perumahan Perum 2 dan Perum 3 yang terdapat adanya kegiatan pembangunan perumahan. Dalam menganalisis penelitian ini, peneliti meneliti perubahan kondisi lingkungan sebelum dan sesudah pembangunan, dan peneliti aktivitas masyarakat yang dilakukan setelah pembangunan perumahan tersebut terjadi. Dengan melakukan penelitian tersebut, peneliti menggunakan teori mengenai kaitan antara Arsitektur dengan masyarakat serta lingkungannya yaitu teori oleh Amos Rapoport "Culture, Architecture and Design" serta teori dari Jahn Gehl "Life Between Buildings". Metode penelitian yang digunakan oleh peneliti adalah kualitatif deskriptif agar dapat menjelaskan secara faktual terhadap fenomena yang terjadi. Hasil akhir dari penelitian ini menunjukkan adanya dampak positif dan negatif yang terjadi dari pembangunan perumahan di Kelurahan Parung Panjang, pada perumahan Perum 2 dan Perum 3 yang mempengaruhi kondisi lingkungan serta aktivitas masyarakat didalamnya.
\end{abstract}

Kata kunci: aktivitas, lingkungan, pembangunan, perubahan, perumahan

Info Artikel:

Dikirim: 11 Februari 2021; Revisi: 24 Februari 2021; Diterima: 17 Maret 2021; Diterbitkan: 31 Maret 2021

(C)2021 The Author(s). Published by Arsitekno, Architecture Program, Universitas Malikussaleh, Aceh, Indonesia under the Creative Commons Attribution 4.0 International License (https://creativecommons.org/licenses/by/4.0/).

\section{PENDAHULUAN}

Pada era yang semakin bertumbuh dan berkembang ini, arsitektur memiliki banyak peran untuk mewujudkan lingkungan yang merespon aktivitas serta kebutuhan masyarakat didalamnya. Seperti yang dikatakan oleh Amos Rapoport didalam bukunya yang berjudul Culture, Architecture, and Design (2005), arsitektur tidak hanya membentuk sebuah ruang secara fisik tetapi juga membentuk dan menata lingkungan masyarakat dengan aktivitas, tata ruang, dan juga ruang sosial bagi masyarakat didalamnya [1]. Bidang arsitektur yang mempelajari serta merancang tata ruang dan lingkungan adalah arsitektur perancangan kota atau juga yang dapat disebut dengan arsitektur urban.

Arsitektur urban merespon keadaan secara keseluruhan yang terjadi pada suatu lingkungan dan juga masyarakat didalamnya untuk menciptakan sebuah lingkungan yang responsif. Ada beberapa elemen yang perlu diperhatikan dalam mewujudkan sebuah lingkungan yang baik. Elemen tersebut di antaranya adalah fasilitas pendukung bagi masyarakat, ruang publik masyarakat, ruang sosial, pendapatan ekonomi, demografi, akses dan ketersediaan kendaraan umum. Beberapa elemen tersebut dapat memberikan dampak positif dan negatif bagi lingkungannya sesuai kondisi yang terjadi. Lingkungan besar seperti perkotaan tentu tidak 
dimungkiri memiliki masalah yang terjadi didalamnya. Salah satu elemen yang sering ditemukan mengundang masalah bagi suatu lingkup perkotaan besar adalah tingginya jumlah kepadatan penduduk dan juga keterbatasan lahan untuk pembangunan.

Kota Tangerang Selatan merupakan salah satu kota yang dipengaruhi oleh kepadatan penduduk dari Kota Jakarta [2]. Pada laman berita kabartangsel.com, menyebutkan bahwa adanya peningkatan yang signifikan setiap tahunnya pada Kota Tangerang Selatan yang menjadikan jumlah penduduk pada tahun 2019 sebanyak 1.747 .904 jiwa atau 11.875 jiwa/km² [3]. Peningkatan jumlah penduduk di Kota Tangerang Selatan ini disebabkan oleh maraknya pembangunan perumahan yang merespon kebutuhan ruang tinggal bagi penduduk yang beraktivitas di wilayahnya. Melihat kondisi lingkungan pada wilayah Kota Tangerang Selatan yang sudah semakin padat perumahan, upaya pembangunan perumahan kembali dilaihkan pada wilayah pinggiran Kota Tangerang Selatan. Salah satu wilayah tersebut adalah Kecamatan Parung Panjang. Dalam kasus ini, penulis melihat wilayah Kecamatan Parung Panjang yang menjadi wilayah peralihan penduduk dari Kota Tangerang Selatan.

Kecamatan Parung Panjang merupakan sebuah wilayah dari Kabupaten Bogor yang terletak di perbatasan antara Legok Tangerang dan juga Kabupaten Bogor itu sendiri. Parung Panjang memiliki akses transportasi kereta api (transit) yang memudahkan masyarakat untuk berpergian keluar dan masuk. Masyarakat Kecamatan Parung Panjang secara besar adalah masyarakat dengan kelas menengah ke bawah karena daerahnya yang merupakan pedesaan. Mulai pada tahun 2015 sampai 2020 ini, terdapat adanya aktivitas pembangunan perumahan di Kecamatan Parung Panjang. Pembangunan perumahan tersebut adalah perumahan untuk masyarakat menengah hingga masyarakat menengah ke atas. Pembangunan perumahan tersebut merupakan salah satu upaya peralihan penduduk dari Kota Tangerang Selatan. Hal tersebut dapat dilihat dari nama perumahan yang membawa unsur bahasa lain dan juga membawa nama 'Serpong' yang merupakan salah satu wilayah di Kota Tangerang Selatan. Pembangunan perumahan tersebut tentu memberikan beberapa perubahan di Kecamatan Parung Panjang itu sendiri. Perubahan tersebut di antaranya adalah kenaikan jumlah penduduk, kepadatan kendaraan, kondisi lingkungan dan juga ruang sosialisasi masyarakat. Selain itu juga, terdapat aktivitas masyarakat pada bangunan perumahan yang belum dihuni oleh pemikinya. Perumahan tersebut dijadikan sebagai tempat aktivitas sekelompok orang untuk berkumpul bagi para pemuda dan pemudi baik dari kampung disekitar perumahan maupun dari perumahan itu sendiri.

\section{METODE PENELITIAN}

Sesuai dengan topik dan juga tujuan dari penelitian ini, yaitu untuk mengetahui dampak pembangunan perumahan terhadap kondisi lingkungan dan juga aktivitas masyarakat di Kecamatan Parung Panjang, jenis penelitian ini adalah metode kualitatif deskriptif. Metode kualitatif deskriptif adalah suatu pendekatan penelitian kualitatif yang melihat fenomena yang terjadi dan menjelaskannya secara faktual dan sistematis [4]. Dalam penelitian ini, peneliti menjelaskan studi kasus dan data analisis secara deskriptif. Peneliti akan menganalisis wilayah Kelurahan Parung Panjang dan Kelurahan Lumpang dengan kurang lebih memiliki luas sebesar $1.4 \mathrm{~km}^{2}$. Pada wilayah Kelurahan Parung Panjang dan Kelurahan Lumpang terdapat dua perumahan yang sedang terjadi pembangunan perumahan di dalamnya yaitu, Perum 2 dan Perum 3. Dalam melakukan penelitian perubahan kondisi lingkungan pada wilayah tersebut, peneliti mengambil data peta Kelurahan Parung Panjang dari tahun 2015 sampai dengan 2020. Metode pengumpulan data yang digunakan dalam penelitian ini adalah analisis studi kasus, observasi, wawancara dan juga kuisioner online. Dalam melakukan wawancara, peneliti mewawancarai kepala rukun tetangga serta penduduk yang tinggal di kedua perumahan tersebut untuk mengetahuin kondisi lingkungan serta aktivitas apa yang terjadi baik sebelum dan sesudah adanya pembangunan perumahan tersebut. Selain itu juga peneliti membuat kuisioner yang dijadikan sebagai data pendukung bagi peneliti dalam menganalisis kondisi lingkungan serta perubahan aktivitas yang terjadi. Adapan teknik pengumpulan data penelitian yang diperlukan sehingga proses pengerjaan penelitian ini dapat berjalan secara sistematis.

Dengan metode pengumpulan penelitian secara observasi, wawancara dan dokumentasi, adapun beberapa instrument penelitian yang diperlukan oleh peneliti, di antaranya: 
1. Peta tahun 2015 - 2020 di Kecamatan Parung Panjang, terutama pada wilayah perumahan Perum 2 dan Perum 3. Peta ini didapatkan dari software Google Earth Pro dan kemudian akan diolah oleh peneliti menjadi diagram penelitian

2. Kamera DSLR yang digunakan sebagai alat untuk mengambil gambar kondisi lingkungan dan juga aktivitas masyarakat pada Perum 2 dan Perum 3

3. Perekam suara yang digunakan sebagai alat bantu untuk menyimpan pendapat dan tanggapan narasumber dalam melaksanakan wawancara

4. Kertas dan alat tulis untuk mencatat poin wawancara dan juga mencatatat pemetaan kondisi lingkungan, fungsi perumahan dan juga aktivitas masyarakat

Tabel 1. Tabel Teknik Pengumpulan Data

\begin{tabular}{|c|c|c|c|}
\hline No & Data yang dibutuhkan & Sumber Data & Teknik Penelitian \\
\hline 1 & $\begin{array}{l}\text { Kondisi fisik lingkungan perumahan } \\
\text { Perum } 1 \text {, Perum } 2 \text { dan Perum } 3 \text { dulu } \\
\text { dan sekarang }\end{array}$ & $\begin{array}{l}\text { Informan } \\
\text { Peta Kecamatan } \\
\text { Parung Panjang } 2017 \\
\text { Dokumen }\end{array}$ & $\begin{array}{lr}\text { Wawancara } & \text { dan } \\
\text { pengamatan } & \text { serta } \\
\text { pemetaan } & \text { lapangan, } \\
\text { Penggunaan } & \text { software } \\
\text { GIS } & \end{array}$ \\
\hline 2 & $\begin{array}{l}\text { Aktivitas sosial penduduk pada ketiga } \\
\text { perumahan tersebut sebelum dan } \\
\text { setelah adanya pembangunan } \\
\text { perumahan }\end{array}$ & Informan & $\begin{array}{l}\text { Wawancara dan } \\
\text { pemetaan lapangan }\end{array}$ \\
\hline 3 & $\begin{array}{l}\text { Peralihan fungsi perumahan yang } \\
\text { dijadikan sebagai fungsi lain bagi } \\
\text { penduduk }\end{array}$ & $\begin{array}{l}\text { Informan } \\
\text { Studi Kasus } \\
\text { Dokumen }\end{array}$ & $\begin{array}{l}\text { Wawancara dan } \\
\text { pengamatan lapangan }\end{array}$ \\
\hline
\end{tabular}

\section{HASIL DAN PEMBAHASAN}

Perumahan Perum 2 dan Perum 3 merupakan perumahan yang berada di Kecamatan Parung Panjang. Kedua perumahan tersebut sebagian besar termasuk ke dalam wilayah Kelurahan Parung Panjang dan sebagian kecilnya termasuk ke dalam wilayah Kelurahan Lumpang. Adapun perbatasan yang membatasi wilayah Kelurahan Parung Panjang dan Kelurahan Lumpang yaitu kali (aliran air) yang memotong kedua wilayah tersebut pada bagian selatan [5]. Bagian perumahan yang termasuk pada bagian Kelurahan Lumpang adalah perumahan Perum 2 pada bagian selatan (Jalan Srikaya). Perumahan Perum 2 dan Perum 3 selain termasuk pada wilayah Kelurahan / Desa Parung Panjang juga terbagi kedalam tiga Kepala Dusun (KADUS) atau perangkat desa, diantaranya adalah KADUS 3, 4, dan 5 [6]. Perumahan Perum 2 diberikan tanda yang berwarna merah sedangkan Perum 3 berwarna kuning. Luas wilayah dari kedua perumahan tersebut tentu berbeda jauh, Perum 2 memiliki luas kurang lebih $1.08 \mathrm{~km}^{2}$, sedangkan luas wilayah dari Perum 3 kurang lebih adalah $0.32 \mathrm{~km}^{2}$ [7].

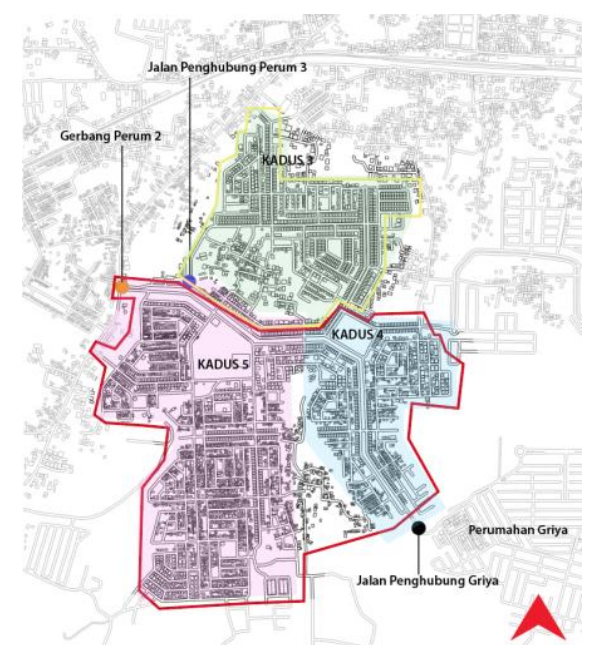

Gambar 1. Pembagian wilayah Perum 2 dan Perum 3 
Pada gambar 1 tersebut memperlihatkan bahwa letak perumahan Perum 2 dan Perum 3 berdekatan dan bahkan keduanya saling berbagi akses atau sirkulasi jalan bagi penghuninya maupun bagi para pengunjung Perum 2 dan Perum 3. Perum 2 memiliki pintu masuk atau yang biasa disebut dengan Gerbang Perum 2 tersendiri yang biasanya tidak hanya dilewati bagi penghuni Perum 2 saja tetapi juga dilewati penghuni wilayah Perum 3 serta Griya (wilayah perumahan sebelah tenggara Kelurahan Parung Panjang). Karena wilayahnya yang begitu luas, perumahan Perum 2 ini dapat terhubung dengan berbagai wilayah perumahan lainnya sehingga menimbulkan interaksi antar penduduk wilayah Perum 2, Perum 3 dan wilayah lain disekitarnya.

Seperti yang sudah dijelaskan sebelumnya, selama kurang lebih 5 tahun yang lalu Kecamatan Parung Panjang, lebih tepatnya pada Kelurahan Parung Panjang mulai terdapat adanya aktivitas pembangunan perumahan pada berbegai wilayah dan salah satunya pada wilayah Perum 3 dan Perum 2. Dengan adanya aktivitas tersebut, adanya perubahan yang terjadi, dan bahkan sangat dirasakan dampaknya bagi penghuni maupun pengunjung pada kedua perumahan tersebut. Secara umum, kawasan perumahan Perum 2 yang sebelumnya memang sudah ramai aktivitas, justru semakin ramai setelah adanya pembangunan perumahan tersebut. Tidak hanya perumahan Perum 2 saja, perkembangan juga terjadi pada perumahan di Perum 3 yang secara garis besar memberikan keramaian aktivitas di dalam wilayahnya. Dengan adanya fenomena tersebut, peneliti menganalisis perubahan kondisi lingkungan dan juga aktivitas apa yang sekarang dilakukan oleh penghuni maupun pengunjung wilayah Perum 2 dan Perum 3 tersebut. Agar penelitian tetap berjalan pada fokusnya, peneliti melakukan observasi dan analisis pemetaan yang lebih pada daerah perumahan pada Perum 2 dan Perum 3 yang berdekatan dengan lokasi pembangunan perumahan baru Sentraland oleh BSALand tersebut.

\section{Analisis Kondisi Lingkungan}

Merunut kepada teori dari Amos Rapoport "Culture, Architecture and Design" mengenai analasis lingkungan mengatakan bahwa ada beberapa aspek yang perlu diperhatikan dalam menganalisis suatu lingkungan [1]. Salah satu diantaranya adalah melihat adanya perubahan rancangan atau fisik dari yang sebelumnya dan yang sekarang terjadi. Hal tersebut dapat berdampak kepada lingkungan itu dan kepada karakter dari masyarakat yang tinggal didalamnya [1]. Agar peneliti dapat melihat keterkaitan karakter penghuni (masyarakat) dan juga lingkungan dari perumahan Perum 2 dan Perum 3, peneliti membuat adanya peta perbedaan lahan maupun fungsi yang terjadi di Perum 2 dan Perum 3.

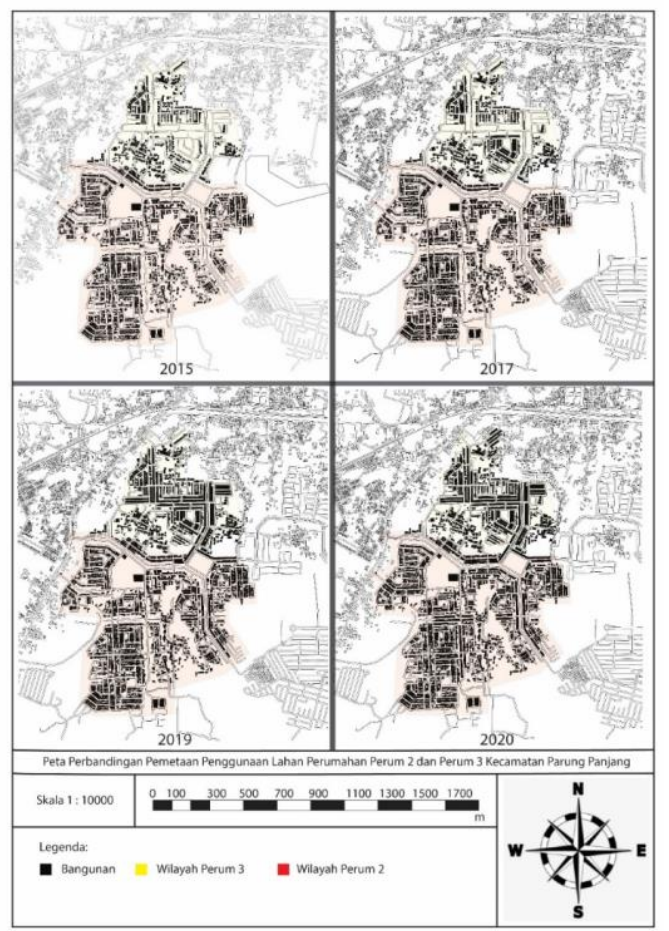

Gambar 2. Peta perbandingan penggunaan lahan perumahan Perum 2 dan 3 Kecamatan Parung Panjang 
Hasil analisis pemetaan serta observasi peneliti yang akan dijelaskan terlebih dahulu adalah pemanfaatan lahan atau penggunaan lahan pada perumahan Perum 2 dan Perum 3. Dalam melakukan analisis dan pembuatan diagram penggunaan lahan tersebut, peneliti melihat adanya perubahan yang cukup besar dari tahun 2015 sampai dengan 2020. Melihat peta pemetaan pada tahun 2015 di bagian perumahan perum 3 (utara) tersebut juga menyatakan bahwa pada tahun 2015 lalu, belum banyak bangunan fisik yang dapat ditemui di Perum 3 sehingga membuat wilayah tersebut mati (sepi). Berbeda dengan perumahan Perum 3, pada wilayah perumahan Perum 2 sudah banyak ditemui bangunan fisik yaitu rumah hunian penduduk Perum 2. Hal tersebut dapat terlihat dengan banyaknya kotak berwarna hitam yang menandakan bangunan yang ada di Perum 2. Meskipun sudah memiliki bangunan fisik yang cukup memadati wilayahnya, pada perumahan Perum 2 juga masih dapat menemukan ruang terbuka hijau di sekitarnya.

Pada tahun 2017 juga terdapat perubahan kondisi lingkungan dengan adanya proses terlaksananya penimbunan danau buatan yang berada di wilayah sebelah timur wilayah perumahan Perum 2 dan Perum 3 (pada peta 2015) yang sudah menjadi tanah atau lahan untuk pembangunan perumahan baru Sentraland (pada peta 2017). Dengan sudah terlaksananya penimbunan tersebut, tersedianya akses dan integrasi dari wilayah perumahan Perum 2 dan Perum 3 menuju jalan pada wilayah Kelurahan Kabasiran yang tepat berada di sebelah timur Kelurahan Parung Panjang dengan mudah dan nyaman. Selain adanya akses baru menuju wilayah Kelurahan Kabasiran, wilayah perumahan Perum 3 itu sendiri sudah mulai memiliki akses masuk ke dalam perumahannya melaui jalan raya besar. Melihat kembali kepada peta pemetaan tahun 2017 dan 2019, kondisi yang berubah dalam jangka waktu 2 tahun tersebut adalah sudah adanya pembangunan perumahan pada wilayah Perum 3 terlebih dahulu di tahun 2017. Hal tersebut dapat dilihat dari perbandingan wilayah Perum 3 ada tahun 2017 yang sebelumnya masih banyak terdapat lahan terbuka hijau dan pada tahun 2019 lahan tersebut sudah mulai didapati banyak perumahan baru Sentraland. Tidak hanya pada wilayah perumahan Perum 3 saja, proses pembangunan perumahan Sentraland tersebut berjalan hingga wilayah perumahan Perum 2 di bagian tenggara atau jalan menuju wilayah perumahan Griya. Berikut di bawah ini merupakan rumah baru Sentraland yang dibangun pada kedua wilayah Perum 2 dan Perum 3.

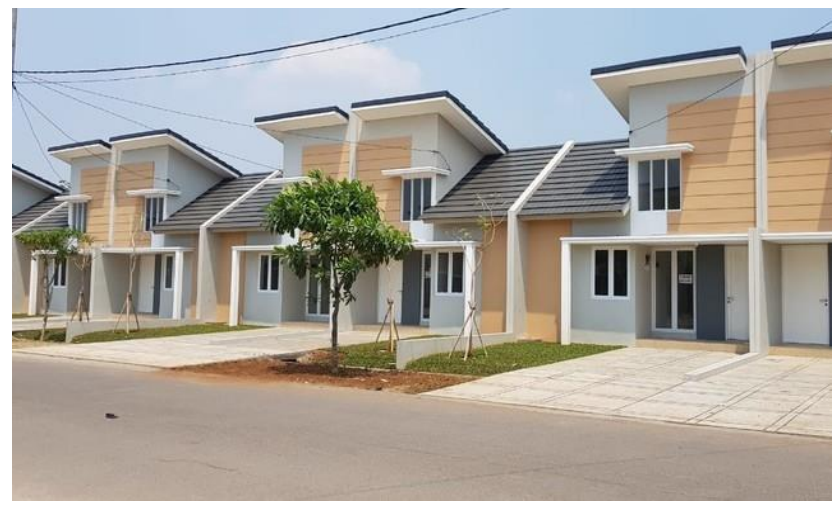

Gambar 3. Perumahan Sentraland

Selanjutnya adalah kondisi lingkungan pada tahun sekarang ini, 2020, yang di mana sudah mulai banyak perumahan baru yang selesai di bangun pada wilayah perumahan Perum 2. Sedangkan pada perumahan Perum 3, ada beberapa rumah-rumah baru sudah mulai ramai dihuni oleh pemiliknya, adanya aktivitas renovasi rumah sesuai keinginan pemiliknya dan bahkan adanya peralihan fungsi bangunan yang sebelumnya berfungsi sebagai hunian menjadi warung, toko, tempat makan dan lain sebagainya. Pada peta pemetaan tahun 2020 tersebut juga terlihat pada kondisi sebelumnya yang kebanyakan lahan hijau kosong, sekarang dipenuhi oleh bangunan fisik yang berfungsi sebagai perumahan. Ketika melihat peta pemetaan tahun 2020 tersebut juga seperti menyatakan bahwa kawasan perumahan Perum 2 dan Perum 3 sudah dipadati perumahan dan banyak penduduk didalamnya. Dalam peta pemetaan tersebut juga dapat terlihat perbedaan perumahan baru oleh pengembang swasta dan negeri dari susunan dan tata letak rumahnya itu sendiri (secara grid). Dengan adanya pembangunan perumahan tersebut pada wilayah itu memberikan perubahan lingkungan menjadi lebih sejuk dan rapih dari sebelumnya. 


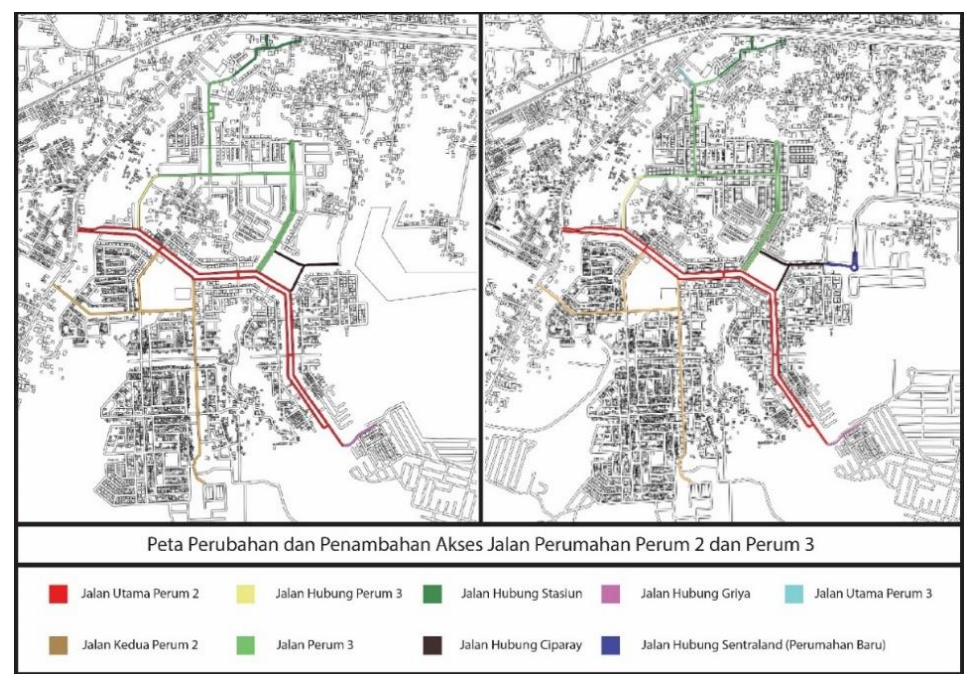

Gambar 4. Peta perubahan dan penambahan akses jalan perumahan Perum 2 dan Perum 3

Setelah adanya pembangunan perumahan baru atau Sentraland tersebut, adanya beberapa perubahan yang terjadi kepada kualitas jalan, bentuk fisik gate dan juga penambahan akses bagi penghuni maupun pengunjung wilayah Perum 2 dan Perum 3 dari beberapa wilayah lain. Dalam menjelaskan perubahan prasana ini peneliti juga membuat pemetaan perubahan dalam bentuk peta untuk peletakan serta penunjuk penambahan akses jalan baru. Peta pemetaan perbandingan tersebut akan menggunakan kondisi pada tahun 2015 dan juga 2020 (sekarang ini). Setelah adanya pembangunan perumahan baru, muncul adanya dua akses baru pada perumahan Perum 2 dan Perum 3. Kedua akses tersebut di antaranya adalah akses pintu masuk Perum 3 (atau sering disebut pintu masuk Sentraland karena perumahan baru) yang diberi warna biru muda dan juga akses perumahan Perum 2 dekat perumahan Blok I menuju perumahan Sentraland utama (yang beri warna biru). Dengan adanya pintu masuk perumahan Perum 3 yang baru tersebut, banyak penduduk yang tinggal pada perumahan Perum 3 itu merasa lebih dimudahkan dan akses untuk menuju jalan besar Parung Panjang lebih dekat [8]. Sementara itu dengan adanya akses jalan yang berhubungan dengan perumahan Sentraland utama memberikan akses yang luas bagi penduduk pada Kelurahan Kabasiran untuk memasuki perumahan Perum 2 dan Perum 3. Menurut peneliti, penyebab adanya peningkatan aktivitas pedagang kaki lima pada wilayah lahan kosong di Perum 2 maupun Perum 3 adalah dibukanya kedua akses baru tersebut.

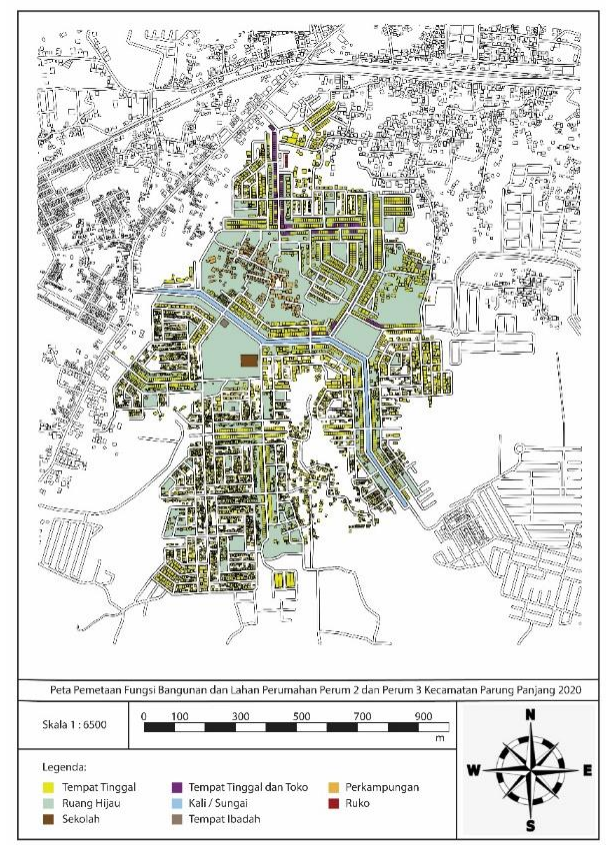

Gambar 5. Pemetaan lahan dan fungsi bangunan Perum 2 dan Perum 3 


\section{Analisis Aktivitas Masyarakat}

Dalam melakukan analisis aktivitas masyarakat, peneliti menganalisa aktivitas masyarakat setelah adanya pembangunan perumahan baru Sentraland pada wilayah Perum 2 dan Perum 3. Hasil analisis yang dijelaskan diantaranya adalah hasil dari pengamatan pribadi peneliti, wawancara, dan kuisioner. Adapun peta pemetaan fungsi bangunan dan lahan perumahan yang akan menjadi media bantu peneliti menyesuaikan data yang didapatkan dari wawancara dan kuisioner. Pertama-tama, peneliti akan membahas aktivitas penduduk maupun pengunjung pada wilayah perumahan Perum 3 yang berdekatan dengan wilayah pembangunan perumahan baru yaitu Sentraland Blok H dan Blok I. Pada awal pembangunan perumahan selesai dan mulai dapat dihuni, fungsi bangunan tersebut tentunya adalah sebagai tempat hunian bagi pemiliknya. Setelah mulai banyak dihuni oleh pemiliknya, adapun perubahan atau penggandaan fungsi bangunan yang terjadi pada wilayah perumahan Blok H lalu diikuti oleh perumahan Blok I. Dengan terjadi peralihan fungsi bangunan dan penggandaan fungsi bangunan tersebut mengundang banyak aktivitas baru pada kedua Blok perumahan tersebut. Setelah adanya pembangunan perumahan baru ini di wilayah Perum 3 memberikan perubahan besar untuk aktivitas penduduk maupun pengunjung didalamnya. Seperti dengan adanya perumahan yang berfungsi sebagai toko maupun warung dan juga adanya ruko tersebut mengundang banyak pengunjung dari wilayah lain untuk beraktivitas meramaikan wilayah Perum 3 tersebut. Selain itu juga penghuni atau penduduk perumahan di Perum 3 tersebut merasa kebutuhannya terpenuhi dengan banyaknya warung, toko maupun tempat makan tersebut di daerah perumahannya.

Pembahasan selanjutnya adalah analisa aktivitas masyarakat pada wilayah Perum 2 yang adanya terdapat perumahan baru Sentraland. Perumahan Sentraland Blok K sementara untuk perumahan Sentraland Blok J. Perumahan baru pada wilayah Perum 2 ini lebih banyak digunakan hanya sebagai tempat tinggal dan juga ada yang belum dihuni oleh pemiliknya menjadikan perumahan itu kosong. Mengingat pada bagian kondisi lingkungan yang sudah dijelaskan sebelumnya, perumahan Sentraland Blok K tersebut sudah lebih dulu selesai pada tahun 2019 sehingga beberapa perumahan pada wilayah tersebut sudah dihuni oleh pemiliknya, ada beberapa rumah yang dialih fungsikan menjadi warung dan toko. Setelah melakukan pengamatan aktivitas yang dilakukan pada wilayah dekat perumahan Blok K tersebut, aktivitas yang banyak ditemui adalah pada sore sampai malam hari terutama pada malam minggu dan pada pagi hari di hari minggu. Aktivitas dilakukan oleh pengunjung perumahan wilayah Blok K pada malam minggu dan minggu pagi itu dilakukan pada teras perumahan kosong yang belum dihuni tersebut sebagai tempat untuk bermain, berkumpul dan 'nongkrong' bagi mereka. Aktivitas tersebut sering dilakukan oleh pengunjung tersebut sehingga membuat perumahan kosong itu menjadi kotor dan didapati banyak sampah di teras maupun di tamannya [9].

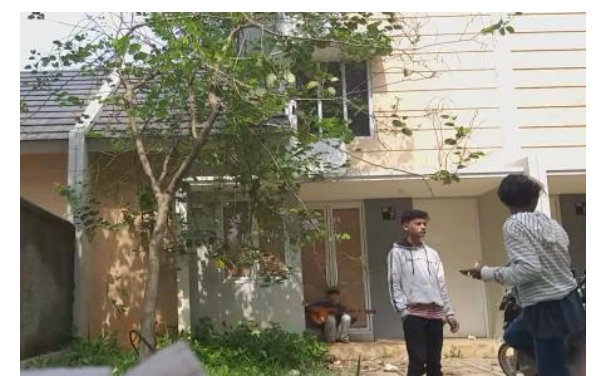

Gambar 5. Aktivitas pengunjung wilayah pada Minggu pagi

Pada sepanjang jalan utama Perum 2 tersebut terdapat aktivitas yang dilakukan pada waktu tertentu, Pada hari biasa di sore hari, aktivitas yang dilakukan pada jalan tersebut adalah berdagang, jalan sore dan membeli makanan atau jajanan. Berbeda pada minggu pagi, aktivitas yang dilakukan pada wilayah Perum 2 tersebut jauh lebih ramai dikarenakan adanya pasar sederhana dan juga banyak pedagang sembako dan pedagang lainnya yang berjualan pada sepanjang jalan Perum 2 tersebut. Selain itu juga pada minggu pagi hari diramaikan lagi oleh kegiatan olahraga pagi seperti lari pagi, maupun jalan pagi oleh penduduk maupun pengunjung wilayah Perum 2. Selain adanya aktivitas pada jalam utama Perum 2 tersebut, aktivitas lainnya juga dapat terihat pada wilayah jalan penghubung antara wilayah Perum 2 dan Perum 3. Sama 
seperti aktivitas yang sering ditemukan pada wilayah jalan Perum 2, perumahan Blok $\mathrm{H}$ dan juga perumahan Blok I, aktivitas pada jalan Perum 3 ini lebih banyak berdagang atau pedagang kaki lima. Aktivitas tersebut rutin dilakukan setiap harinya yang dimulai dari jam 16.00 sampai dengan larut malam. Dengan adanya aktivitas berdagang tersebut membuat daerah sepanjang jalan Perum 3 tidak sepi ketika melewatinya pada malam hari. Aktivitas tersebut sebelumnya sudah dilakukan pada waktu sebelum pembangunan perumahan itu terjadi tetapi tidak begitu banyaknya pedagang kaki lima yang berjualan. Hal tersebut disebabkan adanya perbedaan kondisi lingkungan pada masa sebelum pembangunan dan setelah pembangunan. Adapun data penelitian yang didapatkan oleh peneliti selama melakukan observasi pada tabel 2 .

Tabel 2. Aktivitas Masyarakat di Perum 2 dan Perum 3 Sebelum Pembangunan

\begin{tabular}{|c|c|c|c|c|c|c|c|c|c|c|}
\hline \multirow{2}{*}{ No } & \multirow{2}{*}{ Nama Aktivitas } & \multirow{2}{*}{ Wilayah } & \multirow{2}{*}{ Jam } & \multicolumn{7}{|c|}{ Hari } \\
\hline & & & & $\mathrm{Sn}$ & $\mathrm{Sl}$ & $\mathrm{R}$ & $\mathrm{K}$ & $\mathrm{J}$ & $\mathrm{St}$ & $\mathrm{M}$ \\
\hline 1 & Pasar Kaget & $\begin{array}{c}\text { Jalan } \\
\text { Perum } 2\end{array}$ & $7.00-11.00 \mathrm{WIB}$ & & & & & & & $\mathrm{X}$ \\
\hline \multirow{2}{*}{2} & \multirow{2}{*}{$\begin{array}{l}\text { Berdagang } \\
(\mathrm{PKL})\end{array}$} & $\begin{array}{c}\text { Jalan } \\
\text { Perum } 2\end{array}$ & \multirow{2}{*}{15.00 - malam } & $\mathrm{X}$ & $\mathrm{X}$ & $X$ & $\mathrm{X}$ & $\mathrm{X}$ & $\mathrm{X}$ & $\mathrm{X}$ \\
\hline & & $\begin{array}{c}\text { Jalan } \\
\text { Perum } 3\end{array}$ & & $\mathrm{X}$ & $\mathrm{X}$ & $\mathrm{X}$ & $\mathrm{X}$ & $\mathrm{X}$ & $\mathrm{X}$ & $\mathrm{X}$ \\
\hline \multirow{2}{*}{3} & \multirow{2}{*}{$\begin{array}{l}\text { Jual }- \\
\text { (Jajanan) }\end{array}$} & $\begin{array}{c}\text { Jalan } \\
\text { Perum } 2\end{array}$ & \multirow{2}{*}{15.00 - malam } & $\mathrm{X}$ & $X$ & $\mathrm{X}$ & $\mathrm{X}$ & $\mathrm{X}$ & $\mathrm{X}$ & $\mathrm{X}$ \\
\hline & & $\begin{array}{c}\text { Jalan } \\
\text { Perum } 3\end{array}$ & & $\mathrm{X}$ & $\mathrm{X}$ & $X$ & $\mathrm{X}$ & $\mathrm{X}$ & $\mathrm{X}$ & $\mathrm{X}$ \\
\hline 4 & $\begin{array}{l}\text { Olahraga (Sepak } \\
\text { Bola) }\end{array}$ & $\begin{array}{c}\text { Lapangan } \\
\text { Depan } \\
\text { Blok I }\end{array}$ & $15.00-17.00$ & $\mathrm{X}$ & $\mathrm{X}$ & $\mathrm{X}$ & $\mathrm{X}$ & $\mathrm{X}$ & $\mathrm{X}$ & $\mathrm{X}$ \\
\hline 5 & Lari pagi & $\begin{array}{c}\text { Jalan } \\
\text { Perum } 2\end{array}$ & $7.00-10.00 \mathrm{WIB}$ & & & & & & & $\mathrm{X}$ \\
\hline
\end{tabular}

Tabel 3. Aktivitas Masyarakat di Perum 2 dan Perum 3 Setelah Pembangunan

\begin{tabular}{|c|c|c|c|c|c|c|c|c|c|c|}
\hline \multirow{2}{*}{ No } & \multirow{2}{*}{ Nama Aktivitas } & \multirow{2}{*}{ Wilayah } & \multirow{2}{*}{ Jam } & \multicolumn{7}{|c|}{ Hari } \\
\hline & & & & $\mathrm{Sn}$ & $\mathrm{Sl}$ & $\mathrm{R}$ & $\mathrm{K}$ & $\mathrm{J}$ & St & $\mathrm{M}$ \\
\hline 1 & Pasar Kaget & $\begin{array}{c}\text { Jalan } \\
\text { Perum } 2\end{array}$ & $7.00-11.00 \mathrm{WIB}$ & & & & & & & $\mathrm{X}$ \\
\hline \multirow{4}{*}{2} & \multirow{4}{*}{$\begin{array}{l}\text { Berdagang } \\
\text { (PKL) }\end{array}$} & $\begin{array}{c}\text { Jalan } \\
\text { Perum } 2 \\
\end{array}$ & \multirow{4}{*}{15.00 - malam } & $\mathrm{X}$ & $\mathrm{X}$ & $\mathrm{X}$ & $\mathrm{X}$ & $\mathrm{X}$ & $\mathrm{X}$ & $\mathrm{X}$ \\
\hline & & $\begin{array}{c}\text { Jalan } \\
\text { Perum } 3\end{array}$ & & $\mathrm{X}$ & $\mathrm{X}$ & $\mathrm{X}$ & $\mathrm{X}$ & $\mathrm{X}$ & $\mathrm{X}$ & $\mathrm{X}$ \\
\hline & & Blok H & & $\mathrm{X}$ & $\mathrm{X}$ & $X$ & $\mathrm{X}$ & $\mathrm{X}$ & $\mathrm{X}$ & $\mathrm{X}$ \\
\hline & & Blok I & & $\mathrm{X}$ & $\mathrm{X}$ & $\mathrm{X}$ & $\mathrm{X}$ & $\mathrm{X}$ & $\mathrm{X}$ & $\mathrm{X}$ \\
\hline \multirow{4}{*}{3} & \multirow{4}{*}{$\begin{array}{l}\text { Jual }- \\
\text { (Jajanan) }\end{array}$} & $\begin{array}{c}\text { Jalan } \\
\text { Perum } 2\end{array}$ & \multirow{4}{*}{15.00 - malam } & $\mathrm{X}$ & $\mathrm{X}$ & $\mathrm{X}$ & $\bar{X}$ & $\mathrm{X}$ & $\mathrm{X}$ & $\mathrm{X}$ \\
\hline & & $\begin{array}{c}\text { Jalan } \\
\text { Perum } 3 \\
\end{array}$ & & $\mathrm{X}$ & $\mathrm{X}$ & $\mathrm{X}$ & $\mathrm{X}$ & $\mathrm{X}$ & $\mathrm{X}$ & $\mathrm{X}$ \\
\hline & & Blok H & & $\mathrm{X}$ & $\mathrm{X}$ & $\mathrm{X}$ & $\mathrm{X}$ & $\mathrm{X}$ & $\mathrm{X}$ & $\mathrm{X}$ \\
\hline & & Blok I & & $\mathrm{X}$ & $\mathrm{X}$ & $\mathrm{X}$ & $\mathrm{X}$ & $\mathrm{X}$ & $\mathrm{X}$ & $\mathrm{X}$ \\
\hline 4 & $\begin{array}{l}\text { Olahraga (Sepak } \\
\text { Bola) }\end{array}$ & - & - & - & - & - & - & - & - & - \\
\hline \multirow{3}{*}{5} & \multirow{3}{*}{ Lari pagi } & $\begin{array}{c}\text { Jalan } \\
\text { Perum } 2\end{array}$ & \multirow{3}{*}{$7.00-10.00 \mathrm{WIB}$} & & & & & & & $\mathrm{X}$ \\
\hline & & Blok J & & & & & & & & $\mathrm{X}$ \\
\hline & & Blok K & & & & & & & & $\mathrm{X}$ \\
\hline \multirow{3}{*}{6} & \multirow{3}{*}{$\begin{array}{l}\text { Lari Sore / } \\
\text { Bersepeda }\end{array}$} & $\begin{array}{c}\text { Jalan } \\
\text { Perum } 2\end{array}$ & \multirow{3}{*}{$15.00-17.00 \mathrm{WIB}$} & $\mathrm{X}$ & $\mathrm{X}$ & $\mathrm{X}$ & $\mathrm{X}$ & $\mathrm{X}$ & $\mathrm{X}$ & $\mathrm{X}$ \\
\hline & & Blok J & & $\mathrm{X}$ & $\mathrm{X}$ & $X$ & $\mathrm{X}$ & $\mathrm{X}$ & $\mathrm{X}$ & $\mathrm{X}$ \\
\hline & & Blok K & & $\mathrm{X}$ & $\mathrm{X}$ & $\mathrm{X}$ & $\mathrm{X}$ & $\mathrm{X}$ & $\mathrm{X}$ & $\mathrm{X}$ \\
\hline \multirow[t]{2}{*}{7} & \multirow{2}{*}{$\begin{array}{l}\text { Berkumpul } \\
\text { Nongkrong }\end{array}$} & Blok K & \multirow{2}{*}{$17.00-22.00 \mathrm{WIB}$} & & & & & & $\mathrm{X}$ & \\
\hline & & Blok I & & & & & & & $\mathrm{X}$ & \\
\hline
\end{tabular}




\begin{tabular}{|c|l|c|c|c|c|c|c|c|c|c|}
\hline & & Blok H & & & & & & & X & \\
\hline 8 & $\begin{array}{l}\text { Belanja } \\
\text { Sembako }\end{array}$ & Blok H & $7.00-12.00$ WIB & X & X & X & X & X & X & X \\
\hline
\end{tabular}

Berdasarkan kedua tabel aktivitas yang dilakukan oleh masyarakat Parung Panjang, adanya penambahan aktivitas yang dilakukan pada suatu wilayah dan juga adanya aktivitas yang hilang setelah adanya pembangunan perumahan tersebut. Daerah yang dominasi ramai akan aktivitas penduduk adalah Jalan Utama Perum 2 dan juga Jalan Hubung Perum 3 yang di mana memang sudah ditemui banyak pedagang kaki lima yang berjualan. Adapun juga aktiivtas olahraga yang dilakukan yaitu sepak bola yang dilakukan oleh pemuda yang tinggal pada perumahan Perum 2 itu sendiri [10]. Kegiatan sepak bola tersebut dilakukan pada lapangan hijau yang sekarang ini letaknya tepat di depan perumahan Sentraland Blok I. Setelah adanya pembangunan perumahan tersebut, tanah itu dibeli oleh pengembang kawasan Sentraland dan diberikan batas wilayah sehingga tidak bisa dipakai lagi untuk berolahraga. Meskipun begitu, banyak aktivitas lainnya yang bermunculan setelah adanya pembangunan perumahan baru Sentraland. Pada Tabel 3 dapat terlihat adanya penambahan wilayah untuk aktivitas berdagang (PKL), jual-beli, dan lari pagi. Selain iu juga adanya penambahan kegiatan lari sore, bersepeda, bekumpul / nongkrong hingga belanja sembako. Adanya penambahan kegiatan pada wilayah Perum 2 dan Perum 3 tersebut didukung oleh kondisi lingkungan yang semakin bagus dan nyaman untuk dilalui oleh penduduk maupun pengunjung wilayah.

Merunut kepada teori dari Jahn Gehl yang digunakan dan yang menjadi acuan peneliti dalam meneliti aktivitas masyarakat pada perumahan Perum 2 dan Perum 3, adapun aktivitas yang dilakukan sesuai dengan kategori dari buku Life Between Building. Di antaranya adalah kegiatan penting, kegiatan opsional dan kegiatan sosial. Aktivitas belanja sembako tersebut peneliti masukkan dalam kegiatan penting dikarenakan adanya ditemukan waktu yang berulang-ulang dan sama setiap harinya yang dilakukan oleh penduduk maupun warganya itu sendiri. Aktivitas atau kegiatan lari sore, dan bersepeda yang dilakukan pada wilayah Perum 2 dan Perum 3 merupakan aktivitas atau kegiatan musiman (opsional). Alasan aktivitas tersebut termasuk pada kategori kegiatan musiman (opsional) karena aktivitas tersebut hanya dilakukan hanya pada kondisi tertentu, seperti pada sore hari, keadaan sejuk, banyak rekan dan cuaca bagus. Jika adanya faktor yang tidak mendukung kegiatan tersebut untuk berjalan, pelaku aktivitas juga tidak melakukannya. Sesuai dengan apa yang sudah dibahas oleh peneliti mengenai aktivitas masyarakat Perum 2 dan Perum 3, aktivitas yang sering ditemukan adalah dalam kategori sosial. Aktivitas yang termasuk dalam kegiatan sosial adalah aktivitas yang dilakukan oleh dua orang lebih yang di mana menimbulkan adanya interaksi [2].

\section{KESIMPULAN DAN SARAN}

Berdasarkan penjelasan dari hasil penelitian, dampak perubahan kondisi lingkungan yang terjadi dan yang dirasakan oleh penduduk maupun warga yang beraktivitas pada kedua perumahan tersebut adalah dampak positif. Perubahan pertama yang sangat dirasakan oleh penduduk adalah perubahan kualitas jalan dan akses pada perumahan Perum 2 dan Perum 3. Dengan terjadinya perkembangan kualitas jalan dan juga akses pada perumahan Perum 2 dan Perum 3 memberikan kenyamanan dan kemudahan bagi penduduk maupun pengunjung perumahan untuk beraktivitas didalamnya. Perubahan kedua yang dirasakan adalah munculnya fasilitas seperti toko, warung, pasar kecil dan juga banyak tempat makan pada perumahan baru Blok H dan Blok I. Mengingat pada pembahasan sebelumnya, wilayah Kecamatan Parung Panjang tidak memiliki tempat hiburan bagi penduduknya membuat penduduknya merasa sulit untuk mencari tempat makan maupun hiburan sehingga harus keluar wilayah.

Dampak positif yang dirasakan oleh penduduk diantaranya adalah perubahan prasarana yang lebih bagus dan nyaman dibandingkan sebelumnya. Seperti contoh nyatanya adalah kondisi jalan yang dulu seperti perdesaan yang di mana banyak bolongan dan juga baru kerikil sementara sekarang jalan sudah di cor beton dan diperlebar sehingga nyaman untuk digunakan baik bagi pejalan kaki maupun pengendara mobil atau motor. Dampak positif lainnya adalah wilayah perumahan Perum 2 dan Perum 3 menjadi lebih ramai untuk masyarakat beraktivitas dan juga masyarakat baru yang tinggal di perumahan baru tersebut sehingga dapat meingkatkan kondisi 
ekonomi Kecamatan Parung Panjang itu sendiri. Adapun dampak negatif yang dirasakan oleh penduduk yang lebih banyak mengarah kepada aktivitas yang dilakukan oleh penduduk Perum 2 dan Perum 3 maupun oleh penduduk kampung sekitar di dalam kedua perumahan itu sendiri. Seperti contoh nyatanya penyalahgunaan yang dilakukan pada kondisi jalan tersebut adalah adanya kegiatan balapan pada malam hari yang di mana membuat wilayah menjadi berisik dan tidak aman [11]. Selain itu juga adanya sekelompok pemuda yang melakukan aktivitas tidak jelas pada malam hari seperti berkumpul dan nongkrong dan membuang sampan sembarangan hingga mengotori perumahan yang belum dihuni [10].

Berdasarkan penjelasan tersebut setelah melakukan penelitian ini, merunut kepada teori Amos Rapoport dalam buku "Culture, Architecture and Design", peneliti memahami bahwa ada kaitan erat antara kondisi lingkungan dengan karakter penduduknya itu sendiri sehingga menciptakan terjadinya aktivitas yang dilakukan oleh penduduknya [1]. Dengan keterkaitan tersebut, pada perumahan Perum 2 dan Perum 3 terdapat banyak aktivitas baru dan juga wilayah yang dijadikan tempat penduduk Perum 2 dan Perum 3 untuk beraktivitas setelah adanya pembangunan perumahan baru tersebut. Merunut kepada teori "Life Between Buildings" oleh Jahn Gehl, mengatakan bahwa adanya pengaruh fungsi bangunan pada suatu lingkungan kepada aktivitas atau kegiatan yang terjadi [2]. Aktivitas baru dan aktivitas yang semakin ramai dilakukan oleh penduduk setelah adanya pembangunan perumahan ini adalah berdagang, jual beli dan olahraga.

Setelah melakukan penelitian ini, ada beberapa saran yang dapat diberikan oleh peneliti untuk melakukan penelitian yang lebih baik. Beberapa saran tersebut adalah mengenai pemilihan lokasi analisis, pengumpulan data kepada kelurahan (pemerintah) dan juga mengenai kuisioner online yang akan disebarkan kepada calon responden. Dengan melakukan analisis penelitian mengenai dampak perumahan pada suatu wilayah, akan lebih baik jika studi kasus yang diambil adalah wilayah yang memiliki banyak data terbuka yang disediakan oleh pemerintah wilayahnya itu sendiri sehingga data-data tersebut dapat dengan mudah diperoleh dan juga digunakan untuk membantu penelitian. Saran terakhir dari peneliti adalah mengenai pembuatan kuisioner bagi calon responden yang tinggal pada wilayah Kelurahan atau Desa yang juga dapat dikatakan penduduk yang tidak terlalu modern dalam penggunaan teknologi. Dalam pembuatan kuisioner tersebut hal yang harus diperhatikan adalah membuat pertanyaan yang sederhana sehingga mudah mendapatkan jawaban atau opini dari responden dengan baik dan mudah untuk menyampaikan pendapatnya.

\section{DAFTAR PUSTAKA}

[1] A. Rapoport, Culture, Architecture, and Design. Chicago: Locke Science Publishing Company, 2005.

[2] J. Gehl, Life Between Buildings. Washington: Island Press, 2011.

[3] Kabartangsel, "Jumlah Penduduk Tangsel 2019 Capai 1.747.904 Jiwa,” 2019. [Online]. Available: https://kabartangsel.com/jumlah-penduduk-tangsel-2019-capai-1-747-904-jiwa/.

[4] S. Dharma, "Pendekatan, jenis, dan metode penelitian pendidikan." p. 21, 2008.

[5] F. Zalsabilla and P. Ariastita, "Faktor-faktor yang mempengaruhi ukuran urban compactness di Kota Tangerang Selatan,” 2018.

[6] N. Suryana, "Data kependudukan kelurahan Parung Panjang 2020,” 2020.

[7] Y. Herlinda, "Dampak Aktivitas Jual Beli di Perumahan Blok H Sentraland (Perum 3).” I. Noveryn, 2020.

[8] E. Marpaung, “Kondisi Perumahan Perum 3 Sebelum Perumahan Sentraland.” I. Noveryn, 2020.

[9] M. Malik, "Dampak Pembangunan Perumahan pada Wilayah Perum 2." I. Noveryn, 2020.

[10] Subagio, "Wawancara Wilayah Penduduk Perum 2 RW 11 Kelurahan Parung Panjang," 2020.

[11] N. Suryana, "Data Wialayah dan Kependudukan Perum 2, Perum 3 dari desa Parung Panjang." I. Noveryn, 2020. 